\title{
Editorial: Anti-Trafficking Education: Sites of care, knowledge, and power
}

\author{
Annie Isabel Fukushima, Annie Hill, and Jennifer Suchland
}

Please cite this article as: A I Fukushima, A Hill, and J Suchland, 'Editorial: Anti'Trafficking Education: Sites of care, knowledge, and power', Anti-Trafficking Review, issue 17, 2021, pp. 1-18, https://doi.org/10.14197/atr.201221171

\section{Introduction ${ }^{1}$}

Soon after the World Health Organization (WHO) discovered a mysterious coronavirus in Wuhan, China, in January 2020, the world faced a global pandemic. By July 2021, it was estimated that more than 196 million people were infected and more than 4 million had died, with untold global effects. ${ }^{2}$ The pandemic led to governmental responses such as lockdowns, curfews, and other restrictions on movement that affected schools, services, businesses, families, and communities. Countries around the world wrestled with questions like: How to teach children learning from home? ${ }^{3}$ Who counts as an essential worker? ${ }^{4}$ How to deliver services

1 In the spirit of feminist scholarship, we would like to acknowledge the collaborative nature of this project and that all three guest editors contributed equally. The coeditorship order is alphabetical by last name. We also extend our deep appreciation to the journal's Editor, Borislav Gerasimov, as well as the editorial board, anonymous reviewers, and contributors for their commitment to materialising this project, which was especially commendable during a pandemic.

2 'Coronavirus Resource Center: Global map', Johns Hopkins University \& Medicine, n.d., retrieved 2 August 2021, https://coronavirus.jhu.edu/map.html.

3 F Manca and F Meluzzi, 'Strengthening Online Learning When Schools Are Closed: The role of families and teachers in supporting students during the COVID-19 crisis', Organisation for Economic Co-operation and Development (OECD), 24 September 2020, https://www.oecd.org/coronavirus/policy-responses/strengthening-onlinelearning-when-schools-are-closed-the-role-of-families-and-teachers-in-supportingstudents-during-the-covid-19-crisis-c4ecba6c.

4 N Greenfield, 'COVID-19 Has Exposed the Gross Exploitation of Meatpacking Workers', Natural Resources Defense Council (NRDC), 30 October 2020, https:// www.nrdc.org/stories/covid-19-has-exposed-gross-exploitation-meatpacking-workers; see also H Elver and M Shaprio, 'Violating Food System Workers' Rights in the Time of COVID-19: The quest for state accountability', State Crime Journal, vol. 10, no. 1, 2021, pp. 80-103, https://doi.org/10.13169/statecrime.10.1.0080. 
when social systems are strained or in danger of collapse $?^{5}$ In this context, the anti-trafficking movement, composed of educators, activists, service providers, healthcare workers, and many others, faced demands for distanced connections utilising online learning, telehealth services, Massive Open Online Courses, virtual exchange, and other forms of digitally-mediated communication. ${ }^{6}$

During the pandemic, people began to understand 'Zoom' connections as part of an everyday lexicon where web-video meetings were a central form of communication. While some people saw the possibilities to radically alter and expand education, the pandemic also exacerbated neoliberal market pressures that privilege privatised teaching and learning, entrench the digital divide, and threaten local and Indigenous knowledge systems. ${ }^{7}$ Additionally, it was apparent that vulnerable populations were rendered even more vulnerable due to economic instability, resource scarcity, and heightened conditions of exploitation, to name but a few of the pandemic's effects. ${ }^{8}$ And yet, at the same time, global uprisings for Black lives in the summer of $2020,{ }^{9}$ and protests against anti-Asian rhetoric and racism, ${ }^{10}$ enabled many people to see that education is critical for challenging white

5 E Monaghesh and A Hajizadeh, 'The Role of Telehealth During COVID-19 Outbreak: A systematic review based on current evidence', BMC Public Health, vol. 20, article no. 1193, 2020, https://doi.org/10.1186/s12889-020-09301-4.

6 See B Pattanaik, 'Will Human Trafficking Increase During and After Covid-19?', Global Alliance Against Traffic in Women (GAATW), 6 August 2020, https:/ gaatw. org/blog/1059-will-human-trafficking-increase-during-and-after-covid-19; see also C Murray et al., 'Reconceptualising Relatedness in Education in "Distanced" Times', European Journal of Teacher Education, vol. 43, issue 4, 2020, pp. 488-502, https://doi. org/10.1080/02619768.2020.1806820.

7 T Adams, 'Digital Neocolonialism and Massive Open Online Courses (MOOCs): Colonial pasts and neoliberal futures', Learning, Media and Technology, vol. 44, issue 3, 2019, pp. 365-380, https://doi.org/10.1080/17439884.2019.1640740.

8 'Domestic Workers at the Frontline of the COVID-19 Crisis', International Domestic Workers Federation (IDWF), 30 April 2020, https://idwfed.org/en/covid-19/ domestic-workers; S Ramaswamy and S Seshadri, 'Children on the Brink: Risks for child protection, sexual abuse, and related mental health problems in the COVID-19 pandemic', Indian Journal of Psychiatry, vol. 62, issue 9, 2020, pp. 404-413, https:// doi.org/10.4103/psychiatry.IndianJPsychiatry_1032_20.

9 A Westerman, R Benk, and D Greene, 'In 2020, Protests Spread Across the Globe with a Similar Message: Black Lives Matter', NPR, 30 December 2020, https:/ /www. npr.org/2020/12/30/950053607/in-2020-protests-spread-across-the-globe-with-asimilar-message-black-lives-matt.

10 J Ho, 'Anti-Asian Racism, Black Lives Matter, and COVID-19', Japan Forum, vol. 33, issue 1, 2021, pp. 148-159, https://doi.org/10.1080/09555803.2020.1821749. 
supremacy and colonialism, including within the anti-trafficking movement. ${ }^{11}$ In effect, education became highly visible due to the pandemic because everyone needed to know about the coronavirus and learn new ways to interact, communicate, work, and organise online, in-person, locally, and globally. Lessons from the pandemic regarding structural vulnerabilities, educational modalities, and radical possibilities for change must now be incorporated into the anti-trafficking movement, if it endeavours to challenge interlocking forms of exploitation and oppression occurring across the globe.

The aim of this Special Issue of the Anti-Trafficking Review is to catalyse a collective process of reflection on and evaluation of the current state and stakes surrounding education on human trafficking. The theme of the Special Issue emerged from conversations among the three guest editors several years ago, and it is even more urgent given the pandemic and its compounded effects. The three of us are scholars and educators who have long been invested in critical trafficking studies, albeit from different academic domains that include Ethnic Studies, Rhetoric, and Feminist Studies. ${ }^{12}$ In our conversations, we shared similar concerns about the proliferation of education on human trafficking and how it was frequently framed as an assumed 'good' without critical reflection or evaluation. Today, antitrafficking education extends well beyond the college classroom, accompanied by a significant rise in the sites and stakeholders offering educational resources, such as specialised curricula created for professionals in healthcare, social services, legal professionals, and law enforcement. In the United States, antitrafficking education is also state-mandated for various people and professions, such as for truck drivers in Arkansas and Kansas; ${ }^{13}$ hotel and motel employees

11 See A Jones and H Epping, 'Anti-Racism Work is Essential in the Anti-Trafficking Movement', Freedom Network USA, 26 February 2021, https:/ / freedomnetworkusa. org/2021/03/02/anti-racism-work-is-essential-in-the-anti-trafficking-movement; C Murray, 'Victims and Villains: Anti-trafficking movement urged to tackle racial bias', Reuters, 25 June 2020, https:/ /www.reuters.com/article/us-usa-race-trafficking-trfn/ victims-and-villains-anti-trafficking-movement-urged-to-tackle-racial-biasidUSKBN23W30S.

12 See the following contributions: A Hill and K R Chávez, 'Inciting Communication Across Queer Migration Studies and Critical Trafficking Studies', Women's Studies in Communication, vol. 41, issue 4, 2018, pp. 300-304, https://doi.org/10.1080/074914 09.2018.1544000; A I Fukushima, 'Witnessing in a Time of Homeland Futurities', Anti-Trafficking Review, issue 14, 2020, pp. 67-81, https://doi.org/10.14197/ atr.201220145; and J Suchland, Economies of Violence: Transnational feminism, postsocialism, and the politics of sex trafficking, Duke University Press, Durham, 2015, https://doi. org/10.1515/9780822375289.

13 Act 922, Arkansas, 2017, requires a human trafficking prevention course for the issuance or renewal of a Class 'A' driver's license. In 2018, Kansas Public Safety also required this course. 
in California; ${ }^{14}$ staff at lodging establishments in Florida; ${ }^{15}$ and law enforcement agents in Georgia ${ }^{16}$ and Indiana. ${ }^{17}$ Other states require youth to receive education on trafficking as part of a comprehensive sexual health education. In Southeast Asia, the ride-hailing company Grab is training its drivers to 'spot victims'. ${ }^{18}$ In the Indian state of Odisha, NGOs provided pre-migration training for female migrants as a means to prevent labour-related exploitation. ${ }^{19}$ The argument for much anti-trafficking educational expansion is that people in diverse professions interact with trafficking survivors and those in trafficking situations but lack the knowledge to identify victims or provide assistance. Thus, increasing numbers of people are being trained and taught to take part in anti-trafficking initiatives on their own or in collaboration with police, victim services, and the criminal legal system.

\section{Situating Anti-Trafficking Education}

Given the proliferation of sites for anti-trafficking education, there is a range of educators who shape how publics and institutions understand 'what is human trafficking'. Educators from many different employment sectors are creating formal and informal ways to teach about trafficking as a problem, and how to respond and prevent it. This vast educational reach is possible because learners are encountering anti-trafficking content through workshops, classes, trainings, policymaking sessions, videos, and virtual reality programmes both online and in-person. Unfortunately, educational content on trafficking is often structured by dualities (e.g., victim/criminal, illegal/legal) ${ }^{20}$ and conflated with sexual economies

14 SB 970, California, 2018, amends the Fair Employment Housing Act to require hotels and motels to provide twenty-minute trainings about human trafficking to employees.

15 Title 33 Chapter 509 \$096, Florida, 2019.

16 Title 35 Chapter 1 \35-1-16, Georgia, 2014.

17 Title 5 \& 5-2-1-9, Indiana, 2018.

18 BL Yi, 'Asia Ride-hailing Giant Trains Drivers to Fight Human Trafficking', Reuters, 6 June 2017, retrieved 5 August 2021, https://www.reuters.com/article/us-asiatrafficking-transportation/asia-ride-hailing-giant-trains-drivers-to-fight-humantrafficking-idUSKBN1QS1E1.

19 N S Pocock et al., 'Challenges to Pre-migration Interventions to Prevent Human Trafficking: Results from a before-and-after learning assessment of training for prospective female migrants in Odisha, India', PLoS ONE, vol. 15, issue 1, 2020, e0238778, https://doi.org/10.1371/journal.pone.0238778.

20 A I Fukushima, Migrant Crossings: Witnessing buman trafficking in the US, Stanford University Press, Palo Alto, 2019. 
or other myths ${ }^{21}$ bound to morality. ${ }^{22}$

To grapple with anti-trafficking education, we must address the abundance of antitrafficking teaching and learning in which epistemologies about human trafficking are reproduced and possibilities exist to shift dominant understandings. There is a need to grasp the pedagogies making up the formalised and informalised practices that facilitate learning about trafficking. At its worst, educational content steeped in misinformation and myths fails to contextualise and complicate trafficking, which can lead to dehumanisation and violence, for instance through misguided interventions or 'vigilante rescue'. ${ }^{23}$ At its best, anti-trafficking education can encourage and inform endeavours to create structural change, social justice, and individual empowerment. In the United States, for example, there is knowledgesharing about worker rights by organisations such as the Coalition of Immokalee Workers and the National Domestic Workers Alliance, and trainings to combat housing disparities offered by the Freedom Network USA. Workers' rights organisations, unions, and migrant-led organisations advocate for improved working conditions and against wage theft, violence, and the exploitation endemic to myriad labour sectors, as exemplified by Migrant Forum in Asia's Justice for Wage Theft campaign. By contrast, anti-trafficking education can reproduce a narrow focus on extreme forms of (sexual) violence and remain disconnected from knowledge about and activism for migration and labour rights. We thus ask, what would it take for anti-trafficking education to be more in the service of economic justice, labour rights, and public health than criminalisation? If the expansion of anti-trafficking education is divorced from expansive visions and longstanding movements for equity, then it runs the risk of teaching about trafficking while upholding practices and systems of oppression, exclusion, and expropriation, as well as diverting attention and resources from the ongoing global work toward structural change.

As an educational topic, human trafficking is well-situated for expansive knowledge production and consumption. Yet, under the broad banner of anti-trafficking education, there is a paucity of critical reflection on and evaluation of what is being taught, to whom, and with what effects. One goal of this Special Issue is to identify where the sites of anti-trafficking education are and who participates

21 L Martin and A Hill, 'Debunking the Myth of "Super Bowl Sex Trafficking": Media hype or evidenced-based coverage', Anti-Trafficking Review, issue 13, 2019, pp. 13-29, https://doi.org/10.14197/atr.201219132.

22 C Keo et al., 'Human Trafficking and Moral Panic in Cambodia', The ANNALS of the American Academy of Political and Social Science, vol. 653, issue 1, 2014, pp. 202-224, https://doi.org/10.1177/0002716214521376.

23 E Shih, 'Not in My "Backyard Abolitionism": Vigilante rescue against American sex trafficking, Sociological Perspectives, vol. 59, no. 1, 2016, pp. 66-90, https://doi. org $/ 10.1177 / 0731121416628551$. 
in them. Arguably, the anti-trafficking classes, trainings, workshops, study groups, and virtual reality programmes offered in non-profit, corporate, and governmental organisations make available opportunities for educational excellence and innovation, but they can also disseminate incorrect information while reproducing hierarchical and potentially harmful power relations, ideologies, and attitudes. For example, the growth of anti-trafficking training in social services and healthcare enables the 'carceral creep' commonly found in anti-violence initiatives. ${ }^{24}$ What may appear as a softer or more humane side of the anti-trafficking movement continues to be linked to punitive systems and can result in the criminalisation of survivors and precarious labourers. This carceral creep is likewise elaborated by the criminal legal system's investment in 'penal welfare', that is, services accessible only through contact with the criminal legal system. ${ }^{25}$ Provision of care to survivors is still primarily the outcome of diversion programmes or human trafficking intervention courts, or it coincides with incarceration, and thus even support can hinge on surveillance by the court apparatus. ${ }^{26}$ Carceral creep, and coercion into support services, are pertinent here because anti-trafficking education can be used to legitimise the unequal relations of power (and injustice) embedded in the anti-trafficking movement and the criminal legal system at large.

Additionally, non-profit organisations involved in anti-trafficking initiatives can serve as important collaborators on government-led task forces. The good intentions of employees at non-profit organisations neither necessarily translate into accountable outreach, nor do they always serve the best interests of the people they aim to assist. In tandem with the NGO-ification of the anti-trafficking movement, some organisations function as gatekeepers to anti-trafficking policymaking and may intervene in what research is conducted..$^{27}$ Furthermore,

24 M E Kim, 'The Carceral Creep: Gender-based violence, race, and the expansion of the punitive state, 1973-1983', Social Problems, vol. 67, issue 2, 2020, pp. 251-269, https://doi.org/10.1093/socpro/spz013.

25 A Gruber, A Cohen, and K Mogulescu, 'Penal Welfare and the New Human Trafficking Intervention Courts', Florida Law Review, vol. 68, issue 5, 2016, pp. 1333-1402, https:/ / doi.org/10.2139/ssrn.2776870.

26 K Lerum et al., 'Using Human Rights to Hold the US Accountable for its Anti-Sex Trafficking Agenda: The Universal Periodic Review and new directions for US policy', Anti-Trafficking Review, issue 1, 2012, pp. 80-103, https://doi.org/10.14197/atr.201215; S Foley et al., 'Un-Meetable Promises: Rhetoric and reality in New York City's Human Trafficking Intervention Courts', Report by the Global Health Justice Partnership of the Yale Law School and Yale School of Public Health in collaboration with the Sex Workers Project for the Urban Justice Center, September 2018.

27 J Musto, 'The NGO-ification of the Anti-Trafficking Movement in the United States: A case study of the Coalition to Abolish Slavery and Trafficking', in T Zheng (ed.), Anti-Trafficking, Human Rights, and Social Justice, Wagadu, vol. 5, Xlibris Publishing, Bloomington, Indiana, 2008, pp. 6-20. 
'Trafficking 101' or introductory classes and trainings are now ubiquitous features of college campuses, community events, and workplaces, which are run by instructors with varying degrees of experience and expertise. The question remains, then, what is gained in terms of reducing exploitation and violence via the cottage industry of anti-trafficking education? Does the proliferation of education further entrench an individualised rather than structural response to exploitation? When, where, and why does anti-trafficking education participate in oppression and unequal power relations? And how can this tendency and co-optation be reduced in the service of advancing knowledge that leads to empowerment for more people and the most marginalised?

In our view, anti-trafficking education can reflect the problems endemic to anti-trafficking efforts and it can be an avenue through which to intercede and improve on these efforts. This paradox, which calls for both reform and radical change, is perhaps most evidenced in the incorporation of education that centres survivors of trafficking. For example, trauma-informed care intercedes in anti-trafficking efforts and education by prioritising the needs and knowledge of survivors from within the systems that criminalise and stigmatise them. The incorporation of trauma-informed care pushes against systems that too often criminalise first, before (if ever) caring for people. Moreover, trauma-informed care demands greater recognition that survivors of trafficking can and should speak for themselves and that their knowledge is at once critical to, and critical of, initiatives to stop human trafficking. Hence, it is necessary to centre the people who have direct experience and knowledge of trafficking in educational practices and materials on the topic. Several contributors to this Special Issue call for survivor-led advocacy organisations and survivor consultants to play an active role in the development and delivery of anti-trafficking education. We see the centring of survivors as a long overdue remedy to the human rights deficit in the anti-trafficking movement and its instrumentalisation of survivor stories.

Although caring professions potentially perform an ameliorating role, they can also enable and give cover to the carceral logics alive in anti-trafficking efforts. While there is no single survivor story, the deployment of survivor stories is used to give evidence (not only but including in a legal sense) for the maintenance of a legal apparatus that deems some people sympathetic victims of crime while others are demonised as criminals only deserving of punishment. ${ }^{28}$ For instance, survivor stories, and the desire to foreground some of them as self-evident, perpetuate the status quo that structures the anti-trafficking movement, including the persuasive

28 For an excellent assessment of the fraught aspects of including victims and survivor voices, see B Pattanaik, 'Voices and Participation of Victims, Survivors and Workers: Some reflections on World Day Against Trafficking in Persons', GAATW, 29 July 2021, https://gaatw.org/events-and-news/68-gaatw-news/1107-world-day-againsttip-2021. 
power of the 'ideal victim'. ${ }^{29}$ Moreover, expansion of anti-trafficking trainings into the caring professions can contribute to the hypercriminalisation of the sex trade, which is treated by many as a primary source of violence and trauma. This tendency occurs despite professionals in the fields of public health, nursing, and social work trying not to replicate the overemphasis on trafficking in sexual economies at the expense of attention to other forms of trafficking. ${ }^{30}$ And while some trainers and educators include the diverse perspectives of people in the sex trade, given the history and enduring dominance of 'abolitionist' agendas, there is no guarantee that such perspectives are routinely included, let alone centred, within anti-trafficking education in the caring professions. Overall, education on trafficking needs to incorporate the knowledge and experiences of the people most affected by trafficking and anti-trafficking, including those who endure the collateral damage caused by anti-trafficking interventions in diverse labour sectors, not only the sex trade. ${ }^{31}$

To our surprise, most of the contributions to this Special Issue analyse antitrafficking education in the United States. This skew may be the result of a range of factors such as regional interest, distribution of the call for papers, how countries and people are experiencing the pandemic, and the global focus on research that prioritises COVID-19. Nevertheless, anti-trafficking education has long been a

29 A I Fukushima, 'Has Someone Taken Your Passport? Everyday surveillance of the migrant laborer as trafficked subject', Biography, vol. 42, no. 3, 2019, pp. 561-585, https://doi.org/10.1353/bio.2019.0060.

$30 \mathrm{~N}$ Littenberg and S Baldwin, 'The Ignored Exploitation: Labor trafficking in the United States', in M Chisolm-Straker and H Stoklosa (eds.), Human Trafficking is a Public Health Issue, Springer, Cham, 2017, pp. 67-91, https://doi.org/10.1007/978-3-31947824-1.

31 There are manifold types of collateral damage related to legal and social anti-trafficking contexts, such as the negative impact suspicion of exploitation plays in the lives of people who are already under state surveillance. For example, in the context of massage parlours and nail salons in the United States, the long history of racist and nativist immigration policies impact how workers are treated. In sites deemed potential places of trafficking and labour exploitation, workers are easily caught in a carceral apparatus that can result in police violence, arrest, deportation, and social stigma. Concern about trafficking intensifies border controls and surveillance of migrant workers, which reproduce racialised and gendered stereotypes and harms. See E Lam and A Lepp, 'Butterfly: Resisting the harms of anti-trafficking policies and fostering peer-based organising in Canada', Anti-Trafficking Review, issue 12, 2020, pp. 91-107, https://doi. org/10.14197/atr.201219126; E Lam et al., 'The Double-Edged Sword of Health and Safety: COVID-19 and the policing and exclusion of migrant Asian massage workers in North America', Social Sciences, vol. 10, issue 5, article no. 157, 2021, pp. 1-17, https://doi.org/10.3390/socsci10050157; and J Ham, M Segrave, and S Pickering, 'In the Eyes of the Beholder: Border enforcement, suspect travellers and trafficking victims', Anti-Trafficking Review, issue 2, 2013, pp. 51-66, https://doi.org/10.14197/ atr.20121323. 
focal point for governments, NGOs, and corporations across the globe. ${ }^{32}$ While germane to the US context in which the turn to 'domestic trafficking' contributes to an emphasis on 'sex trafficking', the need to think and teach against this bias is relevant in other contexts. For instance, the UN Trafficking Protocol definition separates 'forced labour' from 'exploitation of the prostitution of others and other forms of sexual exploitation'. This distinction is replicated in research and education on trafficking. Emphasis on the United States likewise translates into less discussion of education specifically addressing non-sexual labour trafficking, such as the 'know before you go' curriculum and predeparture trainings directed at labour migrants, and outreach to industries in which exploitation is prevalent. Although these geographical and labour sector skews limit the Special Issue's scope, the included research articles and forum pieces initiate a timely and muchneeded critical reflection on anti-trafficking education.

Relatedly, another limitation we want to note is a lack of analysis of public education, especially prevention programmes. Prevention remains an underanalysed and underfunded dimension of the anti-trafficking movement. ${ }^{33}$ Antitrafficking education prioritises teaching professionals who may encounter potential victims, rather than reaching potential victims directly. As stated above, this educational shift is significant and opens opportunities to foreground care over criminalisation. But prevention has always been an anti-trafficking goal narrowly focused on individual choice, rather than structural change. ${ }^{34}$ And yet, prevention and public education could play a larger role than they currently do in highlighting the structural forces that contribute to human trafficking and exploitation. The growth in educational sites and stakeholders addressing trafficking has not, to our knowledge, sufficiently boosted social justice mobilisations in support of criminalised survivors, migrant labourers, or the decriminalisation of survival economies, including for people in the sex trade. Rather than build coalitions that resist structural oppression, anti-trafficking education-like the anti-trafficking movement writ large_-often works in isolation from or in contradiction to social

32 See, for example, Office of the Special Representative and Co-ordinator for Combating Trafficking in Human Beings, 'Simulation-Based Training', Organization for Security and Co-operation in Europe (OSCE), n.d., retrieved 19 July 2021, https://www.osce. $\mathrm{org} / \mathrm{cthb} /$ simulation-based-training.

33 See M Lemke, 'Educators as the "Frontline" of Human-Trafficking Prevention: An analysis of state-level educational policy', Leadership and Policy in Schools, vol. 18, issue 3, 2019, pp. 284-304, https://doi.org/10.1080/15700763.2017.1398337; see also J Donohue-Dioh et al., 'Survivors' Conceptualizations of Human Trafficking Prevention; An exploratory study', Evaluation and Program Planning, vol. 83, 2020, https://doi. org/10.1016/j.evalprogplan.2020.101873.

34 J Suchland, 'The Missing "P” in U.S. Anti-Trafficking', The Feminist Wire, 23 November 2015, https://www.thefeministwire.com/2015/11/the-missing-p-in-u-s-antitrafficking-law. 
justice and liberatory movements. ${ }^{35}$

\section{Contributions to the Special Issue}

The full-length research articles in the Special Issue display a diverse array of professional and pedagogical approaches to anti-trafficking education. Contributors detail instructional materials and institutional settings, and what they alternately describe as intersectional, anti-oppressive, team-based, civicallyengaged, trauma-informed, and survivor-led approaches to teaching and learning about human trafficking.

The lead article, by Lara B. Gerassi and Andrea J. Nichols, begins by announcing, 'Social work education in the US that addresses trafficking for sexual exploitation occurs in a white, heteronormative social context'. Bringing the structural conditions of social work to the fore, Gerassi and Nichols argue that intersectional frameworks and anti-oppressive practice should be central to antitrafficking curricula designed for social work students. The authors recount how whiteness and white women have dominated the social work field in the US, and anti-trafficking education must therefore prepare future social workers to address their implicit biases and learn to work with diverse people to create alternative conditions of agency and empowerment. Overall, teaching about trafficking can require confronting the interlocking oppressions within a profession that has only recently turned a critical lens on the production of knowledge and power in social work itself.

Moving from the caring profession of social work to healthcare, Caroline Shadowen, Sarah Beaverson, and Fidelma B. Rigby survey existing research on anti-trafficking education for providers working in hospital emergency departments (ED). Their findings indicate that trainings tailored to the unique logistical and physical constraints of EDs increased providers' confidence in their ability to identify and assist trafficked persons. Given this potential outcome, the authors make the case for a 'team-based approach' to anti-trafficking trainings in the ED setting, and for a curriculum that includes survivors' input and does not focus solely on trafficking in the sex trade. As the authors note from the research, when survivors participate in curriculum development, the 'results are consistently culturally aware, victim/survivor-centred, and trauma-informed, which creates

35 'Human Trafficking and Sex Workers Rights', Freedom Network USA, April 2015, https://freedomnetworkusa.org/app/uploads/2016/12/HT-and-Sex-Workers-Rights. pdf; J Suchland, 'Human Trafficking Awareness Month: Making the connections to social justice', National Underground Railroad Freedom Center, 11 January 2021, https://freedomcenter.org/voice/human-trafficking-awareness-month-makingconnections-to-social-justice-part-i. 
more robust training for providers' in clinical contexts.

While Shadowen $e t$ al. analyse anti-trafficking education in healthcare, Laura A. Dean turns to the educational terrain of academia and the emergent role of 'human trafficking research labs' (HTRL) in universities. Dean reflects on her experiences leading an HTRL to illustrate how this collaborative research site can develop students' critical thinking about human trafficking and their professional skills, particularly if they aim to enter a career in the anti-trafficking sector. Dean contends that HTRLs give students first-hand experience producing original research and working with local anti-trafficking stakeholders but, most significantly, these labs can address the power dynamics inherent to research, education, and legal interventions, thereby helping students to grapple with 'the ethical implications of knowledge production in social justice advocacy'.

Another ethical dimension of anti-trafficking education is the important role of representations. Working from a postcolonial framework, Sallie Yea discusses her university-level teaching to show how survivors' knowledge and narratives are essential to teaching about trafficking. Yea draws on two types of media: narratives by former slaves, forced labourers, and trafficked persons, and documentaries and films made by people who were not victims/survivors or freed slaves. By presenting these media, within a postcolonial framework, Yea helps students to become aware of and resist victim stereotypes. A postcolonial framework centres questions of power and perspective, such as who has agency to have their voices heard and stories told, which foregrounds the continuous need to interrogate the powerful role of representations and how educators use them.

Continuing the focus on higher education, Annjanette Ramiro Alejano-Steele proposes that 'universities can situate themselves within local anti-trafficking initiatives by offering courses to expand organisational capacities to end human trafficking'. In support of this proposition, Alejano-Steele details how her multidisciplinary course on human trafficking is co-created by community partners and students through inclusive, trauma-informed pedagogy. The author outlines key design questions for facilitating civic engagement principles, teaming up with community partners, and supporting college students who are committed to social justice and change. As such, Alejano-Steele illustrates the ways in which both institutional setting and course design enable and constrain anti-trafficking education, as well as innovative strategies to promote community and student empowerment in teaching and learning.

This section of article-length contributions ends with a consideration of the discursive power of failed anti-trafficking education, as illuminated by Bond Benton and Daniela Peterka-Benton. The authors contend with the new and enduring links between anti-trafficking advocacy and conspiracy theory, most recently the rise of QAnon. Tracking the spread of conspiracy theories about the sexual exploitation of children in particular, Benton and Peterka-Benton 
examine how anti-trafficking myths and disinformation are essential to QAnon, and how online theories can lead to real-life threats and violence. Arguing that the anti-trafficking movement also circulates harmful myths about trafficking and its subjects, the authors assert that anti-trafficking education can and should counteract this tendency by actively interrogating misinformation, including historical myths and the burgeoning conspiracy theories of the twenty-first century.

The full-length research articles are followed by a Forum section with shorter pieces addressing anti-trafficking education. The Forum offers examples of pedagogical praxis in which teaching and learning are not offered as a template, but rather as a gesture toward models, inquiry, and frameworks that others may take up, rework, or re-evaluate. Contributors share their educational experiences and strategies to give readers a variety of promising practices within anti-trafficking instruction.

There is a need for pedagogical models and reflexive learning that are committed to grappling with the uncomfortable and unknowable. Two members of an online critical 'modern slavery' study group, Maayan Niezna and Pankhuri Agarwal, detail their work to that end by defining collective principles, organised into themes and cognisant of the pandemic crisis impacting all of the participants' lives. Niezna and Agarwal describe how to engage with anti-trafficking teaching and learning through peer-based education. They provide a strong argument for ongoing critical self-reflection and education for those deemed 'experts' on trafficking. The study group is an inspiring model for the ethics of education and reflection, especially on the most controversial and intractable issues within the field, and it illustrates the radical pedagogy we suggest is necessary for transforming antitrafficking teaching and learning.

Jessica L Peck outlines a train-the-trainers programme for nurses based on a model developed by the National Association of Pediatric Nurse Practitioners. Utilising web-based content and culturally-aware programming for nurse practitioners, Peck describes a particular profession-based strategy to train trainers on child trafficking. This contribution reveals the process by which healthcare professionals, in this case nurses, become viewed as anti-trafficking stakeholders. In explaining the evolution of the educational programme, Peck gives insights into the growing professional investment in training that is driven by feedback and knowledge from anti-trafficking organisations. At the same time, Peck shines a light on the particular quandary that healthcare providers experience when they are confronted with the complex intersections of the extension of both care and systems of criminalisation.

Likewise focusing on healthcare, Preeti Panda, Annette Mango, and Anjali Garg foreground survivors' perspectives and participation in educational programming for healthcare providers. The authors consider how survivor 
expertise can be established in a training and educational programme through a partnership that explicitly fosters equity. To do so, they focus on how a localised partnership strives to create equity among professionals, including survivor experts, by incorporating their testimonies of working together. In contrast to approaches that instrumentalise survivor stories to fit an already existing curriculum, the authors explain the process of partnering with survivors at the very beginning of designing the training. Establishing survivor partnerships requires special attention to hierarchies and a commitment to collaboration as a method to ensure equity.

\section{Concluding the forum section, Danielle Borrelli and Benjamin Thomas Greer} present the recent and evolving development of the California Cybersecurity Institute's virtual reality (VR) human trafficking training programme. VR uses immersive digital scenes to train police officers and frontline professionals to identify trafficking situations and victims. Borrelli and Greer highlight the technological innovation in education and how it may inform and reshape biases in anti-trafficking responses. Showcasing the specific platform of 'serious games' and immersive storytelling, the authors advocate for the benefits of VR in encouraging critical decision-making, empathy, and complex thinking within the context of law enforcement and advocacy organisations. As with any educational content, VR programmes must also contend with the potential myths, biases, and stereotypes that they can reproduce and reinforce. As the authors note, contending with these limitations is crucial if immersive pedagogies are to succeed as harmreducing techniques.

\section{Future Directions in Anti-Trafficking Education}

We close this Editorial by proposing several promising directions in critical anti-trafficking education. As readers enter the Special Issue, we invite them to ponder what pedagogies are used to raise awareness about and intervene in human trafficking. Within various educational sites, modalities, and practices, how might the anti-trafficking movement create and contribute to pedagogies that seek liberatory ends? What are the ways in which anti-trafficking education can work against neoliberal, colonial, and capitalist forms of teaching and learning? There are already diverse traditions and approaches to draw from that foster antioppressive and liberatory goals such as liberation theology, ${ }^{36}$ feminist pedagogies, ${ }^{37}$

36 P McLaren and P Jandrić, 'From Liberation to Salvation: Revolutionary critical pedagogy meets liberation theology', Policy Futures in Education, vol. 15, issue 5, 2017, pp. 620-652, https://doi.org/10.1177/1478210317695713.

37 S L Crawley, J E Lewis, and M Mayberry, 'Introduction - Feminist Pedagogies in Action: Teaching beyond disciplines', Feminist Teacher, vol. 19, no. 1, 2008, pp. 1-12, https://doi.org/10.1353/ftr.0.0021. 
decolonial pedagogies, ${ }^{38}$ and teach-ins, ${ }^{39}$ as well as reflexive and collaborative forms of teaching and learning. Some of the contributions of the Special Issue gesture toward these traditions and approaches while reflecting on power, collective learning, and implicit bias. As ever more institutions and stakeholders engage in anti-trafficking education, this expansion may provide real opportunities to challenge the embedded hierarchies that privilege oppressive forms of knowledge and action, which are certainly present in the anti-trafficking field.

It is important for anyone taking up the work of anti-trafficking education to reflect on why they or their organisation is interested in teaching about trafficking, what is given and gained by specific educational content, and what opportunities and constraints exist for ensuring an empowering and ethical experience for all involved. It is also vital that the history and present impacts of structural racism, anti-Blackness, colonialism, and the intersecting hierarchies of citizenship status, class, caste, gender, sexuality, and ability are acknowledged and addressed as part of the work of anti-trafficking education. What does it mean to take on a 'new' population for care when medicine, science, law, and other institutions of biopower are also sites of control and violence? ${ }^{40}$ Since political concern about human trafficking re-emerged after the Cold War in the mid-1990s and early 2000s, vibrant activist and scholarly communities have formed that advance critical antitrafficking approaches, many of which tackle the human rights deficit created by those early efforts at combatting labour exploitation. ${ }^{41}$ Legal professionals and community groups, such as domestic violence shelters and migrant rights organisations in particular, have been on the frontlines observing the needs of trafficking victims, the deleterious effects of the law, and how enforcement is

38 R Grosfoguel, R Hernández, and E R Velásquez, (eds.), Decolonizing the Westernized University: Interventions in philosophy of education from within and without, Lexington Books, Lanham, 2016.

39 Consider models from the Vietnam War and those that emerged in response to Black Lives Matter.

40 See M Chisolm-Straker, 'Historical Context Matters: Health research, health care, and bodies of color in the United States', in M Chisolm-Straker and K Chon (eds.), The Historical Roots of Human Trafficking: Informing primary prevention of commercialized violence, Springer, Cham, 2021, pp. 257-278, https://doi.org/10.1007/978-3-03070675-3_14; see also J Kaye, Responding to Human Trafficking: Dispossession, colonial violence, and resistance among Indigenous and racialized women, University of Toronto Press, Toronto, 2017.

41 For a close analysis of this genealogy and the role of the end of the Cold War, see Suchland, 2015. 
practised by immigration and police agents. ${ }^{42}$ Additionally, activist academics have contributed, in collaboration with community partners, to critiquing antitrafficking policies, terms, and interventions. Yet, universities remain sites of social exclusion with their own histories of exploitation in the name of education. Such contextual facts are essential to know, as educators and universities continue to be entangled in, rather than separate from, social inequities and the urgent topics of discussion in the classroom.

Current anti-trafficking education on sexual economies is robust, so how might we strategise our teaching and learning to examine industries that produce human trafficking beyond sexual economies, and the power relations that undergird trafficking, including racism, heterosexism, cis-genderism, classism, casteism, nationalism, nativism, and ableism? Recognition is growing that racism, ${ }^{43}$ racialised sexualities, ${ }^{44}$ colonisation, ${ }^{45}$ and other oppressions create differential vulnerabilities and impacts (which we are also now witnessing in relation to COVID-19). As a case in point, recent efforts by the Freedom Network USA and the Housing Project ${ }^{46}$ led to critical conversations and educational programming in the form of webinars that cover issues ranging from emergency to long-term accommodation solutions and housing marginalised communities, such as LGBTIQ+ people, migrant communities, and substance users. Important educational content has also been developed in the labour movement, mapping the links among labour,

42 A Ray and E Caterine, 'Criminal, Victim or Worker: The effects of New York's Human Trafficking Intervention Courts on adults charged with prostitution-related offences', Red Umbrella Project, New York, 1 October 2014, https:/ / nyf.issuelab.org/resource/ criminal-victim-or-worker-the-effects-of-new-york-s-human-trafficking-interventioncourts-on-adults-charged-with-prostitution-related-offenses.html.

43 For work analysing the anti-Blackness of anti-trafficking, see T P Woods, 'Surrogate Selves: Notes on anti-trafficking and anti-blackness', Social Identities, vol. 19, issue 1, 2013, pp. 120-134, https://doi.org/10.1080/13504630.2012.753348; L P Beutin, 'Black Suffering For/From Anti-Trafficking Advocacy', Anti-Trafficking Review, issue 9, 2017, pp. 14-30, https://doi.org/10.14197/atr.20121792; A Hill, 'The Rhetoric of Modern-Day Slavery: Analogical links and historical kinks in the United Kingdom's anti-trafficking plan', philoSOPHLA, vol. 7, no. 2, 2017, pp. 241-260, https://doi. org/10.1353/phi.2017.0023; and K Kempadoo, 'The Modern-Day White (Wo)Man's Burden: Trends in anti-trafficking and anti-slavery campaigns', Journal of Human Trafficking, vol. 1, issue 1, 2015, pp. 8-20, https://doi.org/10.1080/23322705.2015.1 006120.

44 J Hua, Trafficking Women's Human Rights, University of Minnesota Press, Minnesota, 2011.

45 S Hunt, 'Representing Colonial Violence: Trafficking, sex work, and the violence of the law', Atlantis: Critical Studies in Gender, Culture, and Social Justice, vol. 37, no. 2, 2015, pp. 25-39.

46 'Housing Project: Training and technical assistance', Freedom Network USA, n.d., retrieved 5 August 2021, https:/ / freedomnetworkusa.org/training/housing-project. 
exploitation, and immigration. ${ }^{47}$ Lastly, prevention programmes have emerged that connect the violence of colonisation to present cases of missing and murdered Indigenous people. ${ }^{48}$ These are commendable educational efforts that enhance teaching and learning and analyse trafficking as an intersectional issue within and beyond borders.

We would like to see education on human trafficking invested in people who experience 'risk' or face exploitation that may not meet the legal threshold of trafficking as defined by national and international bodies. Legal definitions and carceral responses are often legitimated in educational spaces and used as the only discursive frames available. The foreclosing of alternative frames and radical pedagogies consequently closes possibilities for liberatory education as a response to trafficking and interlocking forms of oppression. Educators must learn from people with knowledge and experiences of trafficking, and avoid the common presumption that professionals need to teach the trafficked, or that the privileged hold more knowledge than vulnerable people. In other words, experts may have no expertise in what it feels like and means to be trafficked or vulnerable to trafficking. Therefore, no one should be teaching about trafficking without including the knowledge of people impacted by trafficking and anti-trafficking efforts, as well as those who have insights into interlocking forms of oppression beyond trafficking.

What would it look like to conceptualise anti-trafficking education that centres liberation for all, not in the 'rescue' sense of the word, but where education is itself liberatory? Paolo Freire offers a framework for educators to subvert oppression called the 'pedagogy of the oppressed', that is, 'a pedagogy which must be forged with, not for, the oppressed (whether individuals or peoples) in the incessant struggle to regain their humanity'. ${ }^{49}$ As we contemplate the liberatory potential of anti-trafficking education, we should begin by considering how organisations and individuals define education. To that end, we suggest bell hooks as a point of departure because she sees education as a 'practice of freedom'. According to hooks, education

47 'Fair Food Program', Coalition of Immokalee Workers (CIW), n.d., retrieved 5 August 2021, https://www.fairfoodprogram.org.

48 See H S J Gordon and T W M Roberts, 'Missing or Murdered Indigenous People: Culturally based prevention strategies', Department of Justice Journal of Federal Law and Practice, vol. 69, no. 1, 2021, pp. 47-70.

49 P Freire, Pedagogy of the Oppressed, $30^{\text {th }}$ Anniversary Edition, Continuum, New York and London, 2000, p. 48. 
is a way of teaching that anyone can learn. That learning process comes easiest to those of us who teach who also believe that there is an aspect of our vocation that is sacred; who believe that our work is not merely to share information but to share in the intellectual and spiritual growth of our students. To teach in a manner that respects and cares for the souls of our students is essential if we are to provide the necessary conditions where learning can most deeply and intimately begin..$^{50}$

This Special Issue invites readers to question and reconsider what is good about anti-trafficking education. What hopeful, necessary, and critical work is fostered by teaching and learning about trafficking? Why and how has antitrafficking education become a good in itself or a commodity that purports to sell knowledge and skills, but that may do more harm than good? How might we come to understand anti-trafficking education as a complex and vexed site of care, knowledge, and power relations? The diffusion of anti-trafficking education into diverse professions, places, and digital platforms should provoke active ambivalence and deep reflection. It should incite inquiries into the nature and scope of anti-trafficking education, and how such endeavours in teaching and learning might be (re)made to promote social justice and liberation.

Annie Isabel Fukushima is an Associate Professor in Ethnic Studies with the School for Cultural \& Social Transformation at the University of Utah. She is the author of the award-winning book, Migrant Crossings: Witnessing buman trafficking in the US (Stanford University Press, 2019). Her research focuses on race, gender-based violence, migration, and witnessing. Fukushima is the CoPrincipal Investigator for the Gender-Based Violence Consortium and a research consultant for the Freedom Network USA. She provides expert testimony across the US on immigration, civil, and criminal cases. Email: a.fukushima@utah.edu

Annie Hill is an Assistant Professor in the Department of Rhetoric and Writing and an affiliate with the Center for Women's and Gender Studies at the University of Texas, Austin. Her recent work connects Queer Migration Studies and Critical Trafficking Studies, and her research focuses mainly on sexual and state violence in the United States and United Kingdom. She is on research teams for a Sexual Violence Prevention Collaboratory and a Sex Trading, Trafficking and Community Well-Being Initiative. Email: anniehill@utexas.edu

50 b hooks, Teaching to Transgress, Routledge, New York and London, 1994, p. 13. 
Jennifer Suchland is an Associate Professor at Ohio State University jointly appointed in the Department of Women's, Gender and Sexuality Studies and the Department of Slavic and East European Languages and Cultures. In addition to ongoing scholarship and teaching in Feminist Studies, Critical Trafficking Studies, and Postsocialist Cultural Studies, she is a collaborator on several public humanities and social justice projects. Most recently, she is an ACLS/Mellon Scholars \& Society Fellow (2020-21) working in collaboration with the National Underground Railroad Freedom Center. Personal website: www.jsuchland.com. Email: suchland.15@osu.edu 